\title{
INFRA PETITA PUTUSAN PENGADILAN TINDAK PIDANA KORUPSI YANG MENEROBOS KETENTUAN PEMIDANAAN MINIMUM
}

Kajian Putusan Nomor 2399 K/PID.SUS/2010

\section{INFRA PETITA IN ANTI-CORRUPTION COURT DECISION THAT BREACH THE GENERAL CRIMINAL PROVISIONS}

\author{
An Analysis of Court Decision Number 2399 K/PID.SUS/2010
}

\author{
Anshar \\ Fakultas Hukum Universitas Khairun \\ Kampus II Universitas Khairun, Ternate 97719 \\ E-mail: ansharnatsir@gmail.com \\ Suwito \\ Sekolah Tinggi Ilmu Hukum Biak \\ Kampus STIH Biak Numfor 98119 \\ E-mail: mrsuwitolawyer@gmail.com
}

Naskah diterima: 12 Oktober 2017; revisi: 22 Juli 2018; disetujui 6 Agustus 2018

http://dx.doi.org/10.29123/jy.v11i2.272

\begin{abstract}
ABSTRAK
Penanganan perkara tindak pidana korupsi menganut sistem pemidanaan minimum bagi pelaku yang diputus bersalah oleh pengadilan. Istilah ketentuan pidana minimum khusus secara normatif diatur dalam Pasal 2 ayat (1) Undang-Undang Nomor 31 Tahun 1999, sebagaimana telah diubah menjadi UndangUndang Nomor 20 Tahun 2001 tentang Pemberantasan Tindak Pidana Korupsi. Pada tataran praktiknya terdapat fenomena adanya putusan pengadilan yang menerobos sistem pemidanaan minimum yang dianut tersebut. Salah satu contoh putusan pengadilan yang ditelaah dalam tulisan ini adalah Putusan Nomor 2399 K/PID.SUS/2010. Permasalahan yang timbul adalah apa saja yang menjadi landasan infra petita
\end{abstract}

hakim dalam menjatuhkan putusan yang menerobos ketentuan pemidanaan minimum dalam perkara tindak pidana korupsi tersebut. Metode dalam penelitian ini menggunakan metode penelitian hukum normatif dengan menggunakan pendekatan undang-undang. Penulis berkesimpulan bahwa putusan pengadilan tindak pidana korupsi yang menerobos ketentuan pemidanaan minimum dalam Undang-Undang Pemberantasan Tindak Pidana Korupsi pada dasarnya diperbolehkan. Sepanjang putusan hakim yang infra petita tersebut memiliki esensi ratio legis yang kuat dan dapat dipertanggungjawabkan, atas dasar alasan pertimbangan nilai keadilan dan pertimbangan judex factie sebagaimana pada perkara a quo.

Kata kunci: putusan, korupsi, pemidanaan minimum. 


\section{ABSTRACT}

In the handling of a corruption case, mandatory minimum penalty is adopted in the criminal justice system for the offender who was found guilty by the court. The term 'mandatory minimum penalty' is normatively regulated in Article 2 paragraph (1) of Law Number 31 of 1999, as amended to Law Number 20 of 2001 concerning Corruption Eradication. In practice there is a phenomenon of a court decision breaching the adopted mandatory minimum penalty. One example of a court decision analyzed hereon is the Decision Number 2399 K/PID.SUS/2010. The arising problem is what the consideration of the judge is for infra petita in imposing decision which breached the mandatory minimum penalty provision in that corruption case. This research uses normative legal research method with legislation approach. It can be concluded that it is basically permissible in the corruption court's decision to breach the minimum penalty provisions as stipulated in the Corruption Eradication Law. Provided that the judge's decision of infra petita, is based on strong legislation ratio and can be accounted for, on the basis of justice value and judex factie considerations as in the a quo case.

Keywords: court decision, corruption, minimum penalty.

\section{PENDAHULUAN}

\section{A. Latar Belakang}

Penanganan perkara tindak pidana korupsi kini menjadi indikator masyarakat dalam menilai berhasil atau tidaknya kinerja aparat penegak hukum untuk menciptakan penegakan hukum di Indonesia. Korupsi di Indonesia menjadi salah satu bentuk problematika dari sekian banyak masalah kebangsaan lainnya. Korupsi ditengarai sebagai penyebab kehancuran ekonomi yang memiliki dampak negatif pada terjadinya multi krisis di hampir semua lini kehidupan berbangsa dan bernegara. Sebagai negara hukum (rechtstaat), Indonesia memiliki perangkat hukum dengan memberlakukan Undang-Undang Nomor 31 Tahun 1999 sebagaimana telah diubah menjadi Undang-Undang Nomor 20 Tahun 2001 tentang Pemberantasan Tindak Pidana Korupsi yang mengatur segala rumusan tindak pidana korupsi yang bersifat materiil dan pola penyelesaian perkaranya yang bersifat formal.

Lahirnya Undang-Undang Pemberantasan Tindak Pidana Korupsi merupakan respon dari negara akibat merajalelanya modus korupsi yang ditengarai sebagai bentuk kejahatan luar biasa yang berakibat pada terjadinya kesenjangan sosial, ekonomi, hilangnya kepercayaan publik terhadap pemerintah dan berbagai permasalahan lainnya. Terdapat beberapa hal yang menarik untuk menjadi bahan kajian para pemikir hukum dalam undang-undang tersebut. Salah satunya adalah diberlakukannya ketentuan pidana minimum khusus di dalam rumusan deliknya terhadap pelaku tindak pidana korupsi. Hal ini tentu berbeda dengan ketentuan pidana pada umumnya yang dikenal dalam KUHP yang lebih mengenal ketentuan pidana maksimum. Ketentuan tersebut sebagaimana tercantum dalam Pasal 2 ayat (1) Undang-Undang Pemberantasan Tindak Pidana Korupsi:

"Setiap orang yang secara melawan hukum melakukan perbuatan memperkaya diri sendiri atau orang lain atau suatu korporasi yang dapat merugikan keuangan negara atau perekonomian negara, dipidana dengan pidana penjara seumur hidup atau pidana penjara paling singkat empat tahun dan paling lama dua puluh tahun dan denda paling sedikit Rp.200.000.000,- dan paling banyak Rp.1.000.000.000,-."

Penentuan ketentuan pidana minimum khusus dalam Undang-Undang Pemberantasan 
Tindak Pidana Korupsi ini juga sebagai bentuk upaya serius dari perumus undang-undang guna mendorong pemberantasan tindak pidana korupsi yang marak terjadi di Indonesia. Atas dasar tersebut, semangat pembentukan undang-undang ini seharusnya diimbangi dengan berbagai ketentuan dan kaidah hukum yang berlaku secara logis, khususnya dalam rumusan delik ketentuan pidana minimum khusus dalam Undang-Undang Pemberantasan Tindak Pidana Korupsi yang pada dasarnya memberikan kesan adanya suatu pemaksaan untuk menunjukkan bahwa keinginan untuk memenuhi tuntutan masyarakat yang menghendaki adanya standar minimal objektif untuk delik-delik tertentu yang sangat dicela dan merugikan masyarakat dan/atau negara, serta delik-delik yang dikualifisir atau diperberat oleh akibatnya dan ketidakpercayaan publik terhadap hakim dalam memutus suatu perkara tindak pidana korupsi.

Hal yang perlu dicermati dalam pencantuman ketentuan pidana minimum khusus dalam Undang-Undang Pemberantasan Tindak Pidana Korupsi, khususnya mengenai tidak adanya formulasi tentang aturan atau pedoman pemidanaan yang pada gilirannya berpotensi menimbulkan masalah yuridis pada saat mengaplikasikan ketentuan pidana minimum khusus tersebut. Setidaknya ketika hakim yang mengadili perkara tindak pidana korupsi yang bersangkutan dihadapkan pada fakta banyaknya faktor yang dapat meringankan terdakwa.

Dalam rumusan delik Undang-Undang Pemberantasan Tindak Pidana Korupsi sudah secara eksplisit ditentukan pidana minimum khususnya, namun dengan argumentasi hukum tertentu, tetap saja batas limit pidana minimum khusus tersebut dapat "diterobos" oleh hakim, atau dengan kata lain terdapat distorsi mengenai ketentuan pidana minimum khusus yang telah diatur secara normatif dalam Undang-Undang Pemberantasan Tindak Pidana Korupsi. Pada tataran pelaksanaannya, terdapat putusan hakim yang menjatuhkan pidana penjara dan pidana denda di bawah batas limit ancaman pidana minimum khusus dengan legal reasoning atau penalaran hukum yang dimiliki oleh majelis hakim. Hal ini kemudian memunculkan problem yuridis di mana terdapat adanya pertentangan prinsip antara mengutamakan tujuan hukum dari sisi kepastian hukumnya ataukah mengedepankan tujuan hukum dari sisi keadilan hukumnya.

Secara implementatif terdapat beberapa putusan hakim yang menjatuhkan pemidanaan kepada pelaku tindak pidana korupsi di bawah batas ancaman yang diatur dalam ketentuan pidana minimum khusus Undang-Undang Pemberantasan Tindak Pidana Korupsi. Hakim yang dalam putusannya menerobos ketentuan pidana mininum khusus ini tentunya memiliki legal reasoning yang dapat dipertanggungjawabkan secara hukum. Sekalipun hal itu akan menimbulkan pertentangan antara dimensi kepastian hukum dan dimensi keadilan hukum.

Contoh adanya satu perkara tindak pidana korupsi, di mana hakim telah menerobos ketentuan pemidanaan minimum yang telah diatur dalam Undang-Undang Pemberantasan Tindak Pidana Korupsi, yaitu Putusan Nomor 2399 K/PID.SUS/2010. Putusan ini menimbulkan polemik hukum, di mana duduk perkara atau posisi kasusnya bermula dari adanya rencana proyek pengadaan pakaian dinas di lingkungan kerja Dewan Permusyarawatan Rakyat Daerah Kabupaten Singkawang.

Ketua Panitia Pelaksana Kegiatan (PPK) yang merupakan terdakwa pada berkas perkara 
lain menunjuk perusahaan terdakwa pada perkara a quo sebagai pelaksana tender proyek tersebut. Hingga masa pelaksanaan proyek selesai tidak ada satu helai potongan pakaian dinas pun yang berhasil diadakan, di mana anggaran pelaksanaan proyek pun telah dicairkan sehingga proyek ini oleh jaksa penuntut umum dianggap telah gagal dan memenuhi unsur tindak pidana korupsi. Terdakwa pada perkara tersebut dinilai sebagai pihak yang ikut serta terlibat dalam pelaksanaan proyek fiktif dan didakwa menggunakan dakwaan tunggal di mana jaksa penuntut umum menerapkan Pasal 2 ayat (1) Undang-Undang Pemberantasan Tindak Pidana Korupsi yang menganut ketentuan pemidanaan minimum.

Pada proses persidangan hingga jatuhnya putusan pemidanaan bagi terdakwa di tingkat kasasi, majelis hakim dinilai telah menerobos ketentuan pemidanaan minimum yang dianut pada pasal yang didakwakan terhadap terdakwa sehingga hal ini memuat permasalahan, mengapa majelis hakim dapat mengecualikan ketentuan pemidanaan minimum yang di mana seharusnya majelis hakim harus patuh pada pelaksanaan ketentuan tersebut. Pada putusan pengadilan tingkat kasasi dalam perkara a quo, majelis hakim menjatuhkan putusan pidana penjara selama satu tahun tanpa pidana denda disertai pidana tambahan uang pengganti. Hal ini tentunya sangat jauh dari prinsip pemidanaan minimum yang dianut dan diatur jelas dalam Pasal 2 ayat (1) Undang-Undang Pemberantasan Tindak Pidana Korupsi.

Pertimbangan putusan majelis hakim tingkat kasasi menilai perbuatan tindak pidana korupsi yang terbukti telah dilakukan oleh terdakwa dianggap mencederai nilai keadilan apabila ketentuan pemidanaan minimum tetap harus diterapkan kepada diri terdakwa. Terdapat beberapa pertimbangan putusan majelis hakim yang menjadi tolok ukur nilai keadilan, sehingga pada perkara a quo ketentuan pemidanaan minimum tidak selazimnya untuk diterapkan.

Tolok ukur nilai keadilan tersebut di antaranya adalah kedudukan terdakwa saat terjadinya tindak pidana korupsi. Jenis kualifikasi perbuatan tindak pidana korupsi terdakwa, dan nilai kerugian keuangan negara yang timbul dari perbuatan terdakwa. Tolok ukur nilai keadilan dari pertimbangan putusan majelis hakim tersebutlah yang menarik untuk dikaji dan menjadi permasalahan sentral, di mana atas tolok ukur tersebut dijadikan majelis hakim sebagai dasar pertimbangan dalam mengesampingkan ketentuan pemidanaan minimum yang dianut dalam Undang-Undang Pemberantasan Tindak Pidana Korupsi.

\section{B. Rumusan Masalah}

Bertitik tolok ukur dari latar belakang di atas, maka permasalahan yang dapat diidentifikasi pada tulisan ini adalah: apakah yang menjadi dasar pertimbangan (ratio legis) hakim dalam menjatuhkan putusan pengadilan tindak pidana korupsi sehingga mengesampingkan sisi normatif ketentuan pidana minimum yang secara rigid dan jelas telah diatur dalam Undang-Undang Pemberantasan Tindak Pidana Korupsi?

\section{Tujuan dan Kegunaan}

Berdasarkan rumusan masalah yang dikemukakan di atas, maka penelitian ini dilakukan dengan tujuan untuk mengetahui dan menganalisis alasan pertimbangan hakim (rasio hakim) dalam menjatuhkan putusan pengadilan yang menerobos ketentuan pemidanaan minimum dalam perkara tindak pidana korupsi. Adapun 
kegunaan penelitian ini diharapkan memberikan manfaat secara teoritis untuk menambah khasanah keilmuan di bidang penegakan hukum pemberantasan tindak pidana korupsi dan memberikan masukan sebagai bahan kajian yuridis dalam penyempurnaan pembahasan ketentuan pidana minimum dalam penanganan perkara tindak pidana korupsi.

\section{Tinjauan Pustaka}

1. Ketentuan Pemidanaan Minimum

Bila membahas topik bahasan mengenai pemidanaan, maka lazimnya kita sedang menelaah salah satu bagian dari putusan pengadilan yang dibuat oleh hakim. Dalam hal ini terdapat pandangan Bredemeier (Ali \& Heryani, 2012: 13) yang memandang bahwa tugas pengadilan adalah untuk membuat suatu putusan yang akan mencegah konflik. Untuk melaksanakan tugasnya itu, pengadilan membutuhkan suatu keadaan atau di dalam istilah yang digunakan oleh Parsons, pengadilan bergantung pada suatu kondisi di mana pengadilan membutuhkan suatu analisis tentang hubungan sebab akibat dari suatu perkara yang dihadapkan ke depan pengadilan (Ali \& Heryani, 2012: 13).

Sanksi pidana memiliki peranan penting dalam menciptakan kepatuhan hukum (compliance). Tirtaatmadjaja (Askin, 2012: 47) menyatakan bahwa untuk menciptakan agar anggota masyarakat mamatuhi hukum maka diperlukan sanksi hukum. Sanksi hukum ini dimaksudkan agar peraturan tersebut dipatuhi oleh anggota masyarakat. Sanksi ini kemudian dipertahankan oleh pemerintah untuk menjadikan anggota masyarakat mematuhi segala bentuk norma sebagaimana dikehendaki oleh peraturan perundang-undangan.
Terkait dengan ketentuan pemidanaan minimum, Arief (2002: 128) menyatakan bahwa ketentuan tersebut adalah bentuk pengecualian untuk delik-delik tertentu yang dipandang sangat merugikan, membahayakan atau meresahkan masyarakat dan delik-delik yang dikualifikasir oleh akibatnya (erfolsqualifizierte delikte) sebagai ukuran kuantitatif yang dapat dijadikan patokan bahwa delik-delik yang diancam dengan pidana penjara di atas tujuh tahun yang dapat diberi ancaman minimum khusus, karena delikdelik itulah yang digolongkan sangat berat.

Menurut KUHP sendiri tidak dikenal adanya ancaman pidana minimum yang ada, hanya ancaman pidana minimum umum sehingga aturan umum berorientasi pada sistem maksimum. Hal ini berbeda dengan norma dalam undangundang khusus yang dibuat untuk suatu tindak pidana tertentu yang pengaturannya berada di luar KUHP seperti tindak pidana korupsi. Terhadap undang-undang khusus tersebut dikenal adanya ancaman pidana minimum khusus terhadap sanksi pidananya baik berupa pidana penjara maupun pidana denda. Standarisasi ancaman pidana minimum khusus tersebut bervariasi dan tidak berpola tergantung kepada jenis tindak pidananya sehingga dalam aturan dan pedoman tidak memiliki acuan yang baku untuk dapat diterapkan.

\section{Hubungan Ancaman Pemidanaan Minimum dengan Tujuan Pemidanaan}

Keberadaan ancaman pemidanaan minimum yang terdapat di dalam suatu undangundang termasuk pula dalam Undang-Undang Pemberantasan Tindak Pidana Korupsi, pada dasarnya mempunyai korelasi yang erat dengan tujuan pemidanaan atau penjatuhan pidana. 
Di mana pemidanaan itu sendiri merupakan bagian terpenting dalam hukum pidana, karena merupakan puncak dari seluruh proses mempertanggungjawabkan seseorang yang telah bersalah melakukan tindak pidana.

Menurut pendapat Ashworth (Huda, 2011: 125) yang menyatakan bahwa hukum pidana tanpa pemidanaan berarti menyatakan seseorang bersalah tanpa ada akibat yang pasti terhadap kesalahannya tersebut. Dari adanya pendapat di atas maka dapat dikatakan bahwa di dalam hukum pidana haruslah ada pemidanaan, supaya ada akibat yang pasti atas kesalahan yang telah dilakukan oleh si pelaku kejahatan.

Terkait dengan pengertian dari sistem pemidanaan, di mana hal ini mencakup pengertian yang sangat luas oleh Hulsman (Mulyadi, 2007: 90) menjelaskan bahwa sistem pemidanaan (the sentencing system) adalah "aturan perundangundangan yang berhubungan dengan sanksi pidana dan pemidanaan" (the statutory rules relating to penal sanctions and punishment). Apabila pengertian pemidanaan diartikan secara luas sebagai suatu proses pemberian atau penjatuhan pidana oleh hakim, maka dapatlah dikatakan bahwa sistem pemidanaan mencakup keseluruhan ketentuan perundang-undangan yang mengatur bagaimana hukum pidana itu ditegakkan atau dioperasionalisasikan secara konkret sehingga seseorang dijatuhi sanksi (hukuman) pidana. Ini berarti semua aturan perundang-undangan mengenai hukum pidana substantif, hukum pidana formal, dan hukum pelaksanaan pidana dapat dilihat sebagai kesatuan sistem pemidanaan.

Menurut P.A.F Lamintang dan Theo Lamintang (Melani, 2014: 110), terdapat tiga pokok pemikiran tentang tujuan yang hendak dicapai dengan adanya pemidanaan, yaitu: 1) untuk memperbaiki pribadi dari penjahat itu sendiri; 2) untuk membuat orang menjadi jera; dan 3) untuk membuat penjahat tertentu menjadi tidak mampu melakukan kejahatan lain.

Hal yang sama diuraikan oleh Moeljatno (Budiman, 2016: 307) bahwa terdapat tiga teori dan tujuan pemidanaan, yaitu: 1) Tujuan pembalasan (teori absolut) yaitu untuk membalas perbuatan pidana yang dilakukan oleh pelaku kejahatan; 2) Teori tujuan (teori relatif) yaitu untuk mencegah terjadinya kejahatan, memberikan rasa takut sehingga orang tidak melakukan kejahatan dan memperbaiki orang yang melakukan kejahatan; dan 3) Teori gabungan antara teori absolut dan teori relatif dengan maksud memberikan perlindungan kepada masyarakat terhadap kejahatan.

\section{Prinsip Kebebasan Hakim dalam Memutus Perkara}

Merujuk pada sistem kekuasaan kehakiman di Indonesia, kata "kebebasan" digunakan terhadap lembaga peradilan (kekuasaan kehakiman yang merdeka), maupun terhadap hakim (kebebasan hakim) sebagai aparatur inti kekuasaan kehakiman. Istilah kebebasan hakim sebagai suatu prinsip yang telah diamanahkan konstitusi, ternyata dalam tataran implementasi personal maupun sosial telah banyak menimbulkan berbagai macam penafsiran. Ketika kata "kebebasan" digabungkan dengan kata "hakim", yang membentuk kata majemuk "kebebasan hakim", maka penafsirannya bermacam-macam. Ada yang menafsirkan bahwa kebebasan hakim merupakan kebebasan yang tidak bersifat mutlak, karena tugas hakim adalah untuk menegakkan hukum dan keadilan. Maka dari itu, kebebasan hakim tidak bersifat 
mutlak dan kebebasan hakim tidak boleh terlepas dari unsur tanggung jawab. Kebebasan hakim bukanlah kebebasan yang mutlak dan tanpa batas yang cenderung menjurus kepada kesewenangwenangan (Bertens, 2013: 94).

Secara normatif, kebebasan hakim dapat ditelusuri mulai dari UUD NRI 1945, UndangUndang tentang Kekuasaan Kehakiman dan Mahkamah Agung yang telah beberapa kali mengalami perubahan. Misalnya sebagaimana yang disebutkan pada Pasal 32 ayat (5) Undang-Undang Nomor 14 Tahun 1985 tentang Mahkamah Agung (sebagaimana telah diubah dengan Undang-Undang Nomor 5 Tahun 2004), kata kebebasan hakim tidak diberikan penjelasan lebih rinci dan lebih teknis oleh undang-undang tersebut. Oleh sebab itu dalam memaknai dan memahami prinsip asas kebebasan hakim harus berada dalam kerangka kontekstual prinsip kemandirian kekuasaan kehakiman.

Secara organisatoris, hakim adalah bagian dari subsistem lembaga peradilan, yaitu sebagai pejabatyangmelaksanakankekuasaankehakiman, sehingga kebebasan hakim harus selalu berada dalam koridor kemerdekaan lembaga kekuasaan kehakiman sebagaimana ditentukan dalam Pasal 3 Undang-Undang Nomor 48 Tahun 2009 tentang Komisi Yudisial yang menyatakan bahwa dalam menjalankan tugas dan fungsinya, hakim wajib menjaga kemandirian peradilan.

Implementasi prinsip kebebasan hakim dalam memutuskan suatu perkara yang ditanganinya, dapat dimaknai bahwa hakim bebas dari campur tangan kekuasaan ekstra yudisial, baik kekuasaan eksekutif maupun legislatif dan kekuatan ekstra yudisial lainnya dalam masyarakat. Hakim dalam memeriksa dan mengadili, bebas untuk menentukan sendiri cara- cara memeriksa dan mengadili suatu perkara, di mana hal ini dapat dimaknai pula sebagai kebebasan hakim dalam konteks kebebasan lembaga peradilan.

Kemandirian hakim dalam wujud prinsip kebebasan hakim dalam memutus setiap perkara yang diajukan kepadanya terbentur dengan pola pikir positivistik yang masih mendominasi pemahaman hukum para aparat penegak hukum di Indonesia. Hukum lebih diartikan dalam tataran formal di mana sesuatu akan disebut hukum apabila telah dituangkan dalam bentuk undangundang. Akibatnya hukum cenderung dimaknai sebatas teks dalam dokumen resmi negara yang disebut perundang-undangan. Hukum dalam teks akan diterapkan dalam peristiwa konkret oleh para penegak hukum (Anggraeni, 2011: 271).

Hakim dalam membuat putusan tidaklah sekadar menjalankan teknis yuridis dan prosedural penerapan ketentuan peraturan perundang-undangan semata-mata. Setiap putusan hakim secara yuridis formal tetap tidak dapat mengabaikan aspek prosedural, namun yang terpenting dari itu semua adalah lahirnya suatu putusan yang dapat mengantarkan para hakim untuk sampai pada tujuan hukum yang sesungguhnya yaitu berkeadilan, bermanfaat, dan berkepastian hukum (Suwito, 2015: 102).

\section{Teori Keadilan}

Terdapat berbagai macam teori mengenai keadilan atau pemikiran bagaimana menciptakan tatanan masyarakat yang adil. Teori-teori tersebut menyangkut hak dan kebebasan, peluang kekuasaan, dan kemakmuran. Terkait dengan topik penulisan ini, penulis lebih mengarah kepada teori keadilan dari filsuf Yunani, Aristoteles. Teori keadilan menurut pandangan Aristoteles dapat 
diamati dalam karyanya berjudul nichomachean ethics, politics, dan rethoric. Spesifik dilihat dalam buku nicomachean ethics, di mana sepenuhnya tujuan hukum ditujukan sematamata hanya bagi keadilan.

Berdasarkan filsafat hukum Aristoteles bahwa yang mesti dianggap sebagai inti dari bahasan filsafat hukum tidak lain karena hukum hanya bisa ditetapkan dalam kaitannya dengan keadilan (Friedrich, 2004: 24). Pada pokoknya pandangan keadilan ini sebagai suatu pemberian 'hak persamaan' tapi bukan 'persamarataan.' Aristoteles membedakan hak persamaannya sesuai dengan hak proporsional. Kesamaan hak pada pandangan manusia merupakan suatu unit atau wadah yang sama. Inilah yang dapat dipahami bahwa semua orang atau setiap warga negara dihadapkan pada hukum yang sama.

Kesamaan proporsional memberikan tiap orang apa yang menjadi haknya sesuai dengan kemampuan dan prestasi yang telah dilakukannya. Lebih lanjut, keadilan menurut pandangan Aristoteles dibagi ke dalam dua macam keadilan, yaitu keadilan distributief dan keadilan commutatief. Keadilan distributif ialah keadilan yang memberikan kepada tiap orang porsi menurut prestasinya, sedangkan keadilan komutatif memberikan sama banyaknya kepada setiap orang tanpa membeda-bedakan perbuatan atau prestasinya dalam hal ini berkaitan dengan peranan dari masing-masing insan manusia (Van Apeldoorn, 2011: 11-12).

\section{METODE}

Penelitian ini merupakan penelitian hukum normatif (Soekanto \& Mamudji, 2011: 14) dengan menggunakan pendekatan perundang-undangan dan konseptual (Marzuki,
2010: 96). Data yang digunakan adalah data sekunder berupa bahan hukum primer (putusan pengadilan) dan bahan hukum sekunder (buku, jurnal, dan laporan-laporan hasil penelitian) melalui studi kepustakaan. Bahan hukum yang terkumpul kemudian dianalisis secara kualitatif lalu kemudian dipaparkan secara deskriptif agar dapat menjawab permasalahan dalam tulisan ini.

\section{HASIL DAN PEMBAHASAN}

Secara implementatif dalam tataran praktik di pengadilan tindak pidana korupsi terdapat beberapa putusan hakim yang menjatuhkan pemidanaan kepada pelaku di bawah batas (limit) ancaman yang diatur dalam ketentuan pemidanaan minimum Undang-Undang Pemberantasan Tindak Pidana Korupsi. Hakim yang dalam putusannya menerobos ketentuan pemidanaan minimum ini tentunya memiliki legal reasoning yang dapat dipertanggungjawabkan.

Putusan yang sedemikian rupa itu dapat disebut sebagai putusan hakim infra petita dikarenakan akan menimbulkan pertentangan antara dimensi kepastian hukum (prosedural) dengan dimensi keadilan hukum (substantif) sekalipun tidak sepenuhnya juga dapat demikian. Sebagai contoh dapat digambarkan adanya satu perkara tindak pidana korupsi, di mana hakim telah menerobos ketentuan pemidanaan minimum yang diatur dalam Undang-Undang Pemberantasan Tindak Pidana Korupsi. Putusan Nomor 2399 K/PID.SUS/2010 dengan posisi perkara sebagai berikut:

"Perkara ini merupakan perkara korupsi pengadaan barang dan jasa berupa pengadaan Pakaian Sipil dan Dinas DPRD Singkawang pada akhir tahun 2007. Total pagu untuk pengadaan pakaian tersebut sebesar Rp.65.000.000,-. Dalam pelaksanaan kegiatan tersebut Ketua PPK 
yang merupakan terdakwa pada berkas perkara yang lain telah menunjuk seorang penjahit untuk melaksanakan kegiatan, namun yang menjadi persoalan rupanya penjahit tersebut tidak memenuhi syarat sebagai penyedia barang/jasa sebagaimana diatur dalam Keppres Nomor 80 Tahun 2003 karena tidak memiliki perusahaan. PPK kemudian menghubungi terdakwa dalam perkara ini untuk meminjamkan perusahaannya yang memang bergerak di bidang konveksi agar syarat-syarat formal penunjukan pelaksana kegiatan terpenuhi. Untuk itu Ketua PPK menjanjikan akan memberikan imbalan sebesar Rp.2.900.000,- dan atas tawaran tersebut terdakwa menyetujuinya. Setelah perusahaan terdakwa ditunjuk untuk melaksanakan tender, uang kemudian dicairkan ke rekening perusahaan terdakwa sebesar Rp.58.000.000,-. Uang tersebut kemudian diserahkan kepada Ketua PPK dengan dikurangi fee sebesar Rp.2.900.000,- sesuai kesepakatan sebelumnya. Namun ternyata uang yang diterima oleh Ketua PPK tersebut tidak pernah diserahkan ke pelaksana kegiatan yang sesungguhnya sehingga akibatnya pekerjaan menjadi gagal dan tidak ada satu potong pakaian dinas pun yang berhasil diadakan" (Rumadan, 2013: 400-401).

Tergambar dalam posisi perkara di atas bahwa terdakwa dituntut turut serta melakukan tindak pidana korupsi yang didakwa dengan dakwaan tunggal Pasal 2 ayat (1) UndangUndang Pemberantasan Tindak Pidana Korupsi bersama-sama dengan Ketua PPK, namun dalam berkas perkara yang terpisah. Pada putusan pengadilan tingkat pertama, terdakwa dinyatakan terbukti dan dijatuhi pidana penjara selama empat tahun dan denda sebesar Rp.200 juta subsider satu bulan kurungan dan uang pidana pengganti sebesar Rp.2.900.000,-. Berlanjut pada putusan pengadilan tingkat banding, hukuman tersebut dikurangi menjadi pidana penjara selama satu tahun dan denda sebesar Rp.200 juta subsider satu bulan kurungan.
Jaksa penuntut umum kemudian mengajukan kasasi dengan alasan pertimbangan bahwa penerapan hukum putusan pengadilan tingkat banding tidak berdasarkan pada ketentuan pemidanaan minimum yang dianut dalam Pasal 2 ayat (1) Undang-Undang Pemberantasan Tindak Pidana Korupsi. Kemudian pada putusan di tingkat kasasi, Mahkamah Agung pada dasarnya memiliki pertimbangan hukum yang sama dengan putusan hakim di tingkat banding.

Mahkamah Agung dalam pertimbangannya berpendapat bahwa model dakwaan tunggal dari jaksa penuntut umum membuat hakim berada pada posisi yang dilematis dikarenakan hakim tidak memiliki ruang untuk memilih penerapan hukum yang tepat dan adil bagi terdakwa. Sehingga Mahkamah Agung dalam perkara ini mengesampingkan ketentuan pemidanaan minimum tersebut dengan tetap memperbaiki putusan pemidanaan sebelumnya menjadi pidana penjara selama satu tahun tanpa pidana denda dan pidana tambahan uang pengganti. Pertimbangan lain majelis hakim tingkat kasasi dalam putusannya menilai bahwa perkara ini dapat mencederai rasa keadilan karena ketidakseimbangan perbuatan terdakwa yang hanya merugikan keuangan negara yang hanya senilai Rp.2.900.000,- dengan tuntutan pidana penjara empat tahun dan pidana denda Rp.200 juta yang dihadapinya berdasarkan ketentuan pidana minimum khusus yang diatur dalam Pasal 2 ayat (1) Undang-Undang Pemberantasan Tindak Pidana Korupsi.

Menurut pandangan penulis, hakim memiliki kewenangan secara mandiri untuk menginterpretasikan dan menilai kebenaran formal dan materiil dari suatu kasus tindak pidana korupsi untuk menjatuhkan putusan atau vonis yang bersesuaian dengan nilai-nilai keadilan. Putusan pemidanaan seperti ini dinilai bagi 
penganut paham positivisme telah melanggar ketentuan hukum positifkarena mengesampingkan ketentuan pidana minimum khusus yang diatur secara rigid dalam undang-undang, namun dalam perspektif lain hakim menilai ketentuan undangundang yang dapat mencederai rasa keadilan bila tetap dipaksakan untuk diterapkan justru akan menimbulkan masalah yang lebih serius di tengah-tengah masyarakat (Suwito et al., 2017: 17-18).

Berdasarkan hal tersebut maka hakim sejatinya memiliki dasar pertimbangan hukum (legal reasoning) yang dapat dijadikan pembenaran terhadap adanya putusan yang menerobos ketentuan pemidanaan minimum yang telah rigid dan jelas diatur dalam Undang-Undang Pemberantasan Tindak Pidana Korupsi. Adapun yang menjadi dasar pertimbangan hukum hakim tersebut antara lain:

\section{1) Pertimbangan Nilai Keadilan}

Pada intinya dalam menggali pertimbangan nilai keadilan dalam setiap putusan, hakim haruslah melalui metode atau proses konstatering, kualifisiening, dan konstituering yang merupakan satu kesatuan utuh dalam putusan hakim. Dengan terpenuhinya syarat-syarat dari setiap tahapan ini akan melahirkan putusan yang adil. Proses tersebut pula menggambarkan lahirnya suatu putusan hakim yang ideal jika memenuhi dua syarat, yaitu syarat teoritis dan syarat praktis. Memenuhi syarat teoritis jika telah sesuai dengan teori yang telah diuji kebenarannya, sedangkan memenuhi syarat praktis jika telah sesuai dengan fakta-fakta yang terjadi saat peristiwa pidana (Arto, 2001: 98-99).

Peristiwa pidana yang diajukan ke pengadilan terlebih dahulu harus dikonstatir oleh hakim. Konstatering peristiwa atau kejadian menurut Mertokusumo (2010: 87) adalah berarti melihat, mengakui atau membenarkan telah terjadinya peristiwa pidana yang diajukan tersebut, akan tetapi untuk sampai kepada konstatering-nya itu hakim harus mempunyai pegangan kepastian. Hakim harus yakin akan konstatering-nya, sehingga konstatering-nya tidak sekadar dugaan atau kesimpulan yang dangkal atau gegabah saja. Hakim haruslah menggunakan sarana-sarana atau alat untuk memastikan tentang peristiwa yang bersangkutan. Jadi mengkonstatir peristiwa, kecuali melihat atau membenarkan telah terjadinya peristiwa atau telah menganggap telah terbuktinya peristiwa pidana tersebut, maka diakui sebagai peristiwa yang benar-benar terjadi. Hal yang harus dikonstatir adalah peristiwa, tetapi untuk sampai pada konstatering harus melakukan pembuktian lebih dahulu. Kegiatan yang dilakukan hakim dalam fase pertama ini semata-mata bersifat logis. Jika hakim telah berhasil mengkonstatir peristiwa, yaitu dengan membenarkan suatu peristiwa, maka peristiwa yang benar tersebut dikualifikasikan ke dalam aturan hukum.

Mertokusumo (2010: 88) menjelaskan bahwa mengualifikasikan peristiwa berarti menilai peristiwa yang telah dianggap terbukti itu termasuk hubungan hukum apa atau yang mana, dengan perkataan lain menemukan hukumnya bagi peristiwa yang telah dikonstatir. Setelah hakim menemukan hukumnya, maka selanjutnya hakim melakukan penerapan hukum (rechts toepassing) terhadap suatu peristiwa tersebut. Untuk selanjutnya peraturan hukum yang ada dapat diterapkan pada peristiwa pidana yang bersangkutan.

Prinsipnya hakim tidak diberi wewenang untuk mengubah suatu undang-undang, tetapi hakim dapat saja menyimpang dari undang- 
undang dalam menjatuhkan putusannya dengan berdasar pada perkembangan kehidupan masyarakat. Putusan hakim tidak dapat dibatalkan atau dianulir oleh siapa saja, kecuali tentunya sesuai dengan saluran yang disiapkan oleh peraturan hukum untuk hal tersebut. Setiap putusan hakim dipandang benar dan tetap sah serta mempunyai kekuatan hukum sepanjang putusan tersebut tidak dibatalkan oleh pengadilan yang lebih tinggi. Apa pun yang diputuskan oleh hakim dipandang sebagai hukum yang berlaku dan dapat dipaksakan keberlakuannya paling tidak terhadap pihak-pihak yang berperkara di pengadilan.

Sesudah hakim mengkonstatir dan mengkualifikasi peristiwa pidana, maka tahapan berikutnya ialah hakim memberi konstitusinya. Hal ini berarti bahwa hakim memberikan keadilan dengan menentukan hukum yang menyelesaikan perkara pidana tersebut. Dalam hal ini Mertokusumo (2010: 89) mengemukakan bahwa hakim mengambil kesimpulan dan adanya premis mayor, yaitu (peraturan) hukum dan premis minor, yaitu peristiwanya. Semisal siapa yang korupsi dihukum: si A terbukti korupsi; si A harus dihukum. Meskipun hal itu merupakan silogisme, akan tetapi tidak semata-mata hanya logika saja yang menjadi dasar kesimpulannya. Keadilan bukanlah produk dari intelek hakim tetapi merupakan spirit hakim untuk menemukan sebuah kebenaran dari suatu peristiwa hukum.

Dalam proses pengambilan keputusan untuk mengakhirisuatuperkara,adakemungkinan hakim dihadapkan pada keadaan yang meragukan antara terbukti atau tidak, demikian pula konflik antara kepastian hukum atau keadilan, antara kepastian hukum atau kemanfaatan (doelmatigheid), mana yang harus dipentingkan? Dalam hal seperti ini diperlukan keberanian dan sikap tegas untuk menciptakan hukum yang adil. Putusan hakim kecuali mempunyai kekuatan mengikat dan memaksa juga mempunyai wibawa, dan wibawa ini ditentukan oleh pertimbangan yang menjadi dasar putusan. Pertimbangan atau alasan-alasan dimaksudkan sebagai pertanggungjawaban sehingga putusan tersebut menjadi objektif.

\section{Putusan Nomor 2399 K/PID.SUS/2010} yang merupakan salah satu bentuk putusan hakim yang telah menerobos ketentuan pemidanaan minimum yang diatur dalam Undang-Undang Pemberantasan Tindak Pidana Korupsi, hakim sejatinya telah melakukan penerobosan hukum terhadap ketentuan penjatuhan pidana penjara dan pidana denda yang sejatinya tidak sesuai dengan perintah undang-undang. Putusan hakim pada pengadilan tindak pidana korupsi yang menerobos ketentuan pemidanaan minimum semata-mata tidak hanya sekadar menegakkan keadilan prosedural semata, namun hakim juga semestinya tetap mempertimbangkan aspek keadilan substansial dari setiap putusan yang dibuat oleh hakim berdasarkan jenis perbuatan yang dilakukan terdakwa.

Perlu dicermati pada poin menimbang dalam putusan pengadilan tingkat kasasi perkara a quo disebutkan, bahwa walaupun perbuatan terdakwa terbukti memenuhi segenap unsur pasal yang didakwakan kepada terdakwa, namun majelis hakim menilai penerapan pemidanaan minimum sebagaimana yang diatur dalam pasal dakwaan yang dimaksud dapat mencederai rasa keadilan, karena ketidakseimbangan antara perbuatan yang dilakukan terdakwa dihubungkan dengan jumlah kerugian negara yang timbul akibat perbuatan terdakwa dan dihubungkan pula dengan besaran nilai yang diperoleh terdakwa oleh sebab perbuatannya tersebut yakni sebesar Rp.2.900.000,--. 
Menurut pertimbangan majelis hakim kasasi bahwa tindak pidana korupsi tidak boleh disikapi secara permisif berapapun nilai kerugian keuangan negara yang timbul karenanya, akan tetapi sebaliknya penjatuhan pidana yang mencederai rasa keadilan juga harus dihindarkan. Majelis hakim kasasi pun mempertimbangkan bahwa hal-hal yang sangat khusus, Mahkamah Agung dalam fungsi mengadili dapat melakukan penerapan hukum terhadap kasus konkret yang dihadapi yang aktualisasinya tidak seutuhnya searah dengan semangat dan kehendak pembuat undang-undang, akan tetapi diselaraskan dengan tuntutan keadilan masyarakat. Dengan demikian penjatuhan pemidanaan kepada terdakwa tersebut dirasa cukup tepat, adil, dan patut serta bersesuaian pula dengan semangat menjawab tuntutan rasa keadilan masyarakat (Suwito, 2017: 52-53).

Putusan pengadilan tindak pidana korupsi yang menerobos ketentuan pemidanaan minimum bukanlah merupakan bentuk ketidaktaatan hakim pada perintah undang-undang. Hal tersebut merupakan bentuk penerobosan hukum oleh hakim atas kemandirian yang dimiliki hakim yang patut diapresiasi, asalkan putusan tersebut sungguh-sungguh memuat intisari dari nilai keadilan seperti pada Putusan Nomor 2399 K/PID. SUS/2010. Pada kondisi seperti ini, sebenarnya hakim menunjukkan jati dirinya bahwa ia tidak hanya menjadi penegak hukum atas dasar perintah undang-undang an sich, melainkan hakim juga bertolok pada hati nuraninya. Hakim dapat saja menjatuhkan pidana di bawah dari ancaman ketentuan pemidanaan minimum berdasarkan Undang-Undang Pemberantasan Tindak Pidana Korupsi asalkan putusan tersebut tidak memiliki unsur kepentingan sehingga dapat mengintervensi putusan hakim, akan tetapi putusan tersebut sungguh-sungguh bernilai objektif dengan menjunjung tinggi rasa keadilan.

Berdasarkan penjelasan tersebut di atas, penulis berpandangan bahwa putusan pemidanaan yang menerobos ketentuan pemidanaan minimum, telah menunjukkan bahwa sebenarnya hakim telah melaksanakan perintah undang-undang atas dasar hukum normatif, atau hukum positif yang berlaku dengan menjunjung prinsip keadilan substansial. Pemberlakuan ketentuan pemidanaan minimum dalam UndangUndang Pemberantasan Tindak Pidana Korupsi tidak hanya dipandang sebagai ketentuan yang kaku tanpa mempertimbangkan rasa keadilan. Sehingga menurut hemat penulis, putusan hakim yang menerobos ketentuan pemidanaan minimum tersebut dapat saja diterima dan dinilai sah sebagai produk hukum dalam bentuk putusan pengadilan sepanjang berdasarkan rasa keadilan dan hati nurani, dikarenakan hakim bukan hanya sebagai penegak hukum dan undang-undang semata, melainkan hakim pun bertindak sebagai penegak keadilan.

\section{2) Pertimbangan Judex Factie}

Berikut ini akan diuraikan ratio legis pertimbangan dari sisi judex factie dari Putusan Nomor 2399 K/PID.SUS/2010 sebagai kasus kasuistik yang dinilai telah menerobos ketentuan pemidanaan minimum yang dianut dalam Undang-Undang Pemberantasan Tindak Pidana Korupsi. Dari pertimbangan judex factie ini melahirkan terobosan hukum oleh hakim atas dasar social-moral justice, dan pertimbangan hukum yang sistematis, jelas, dan logis.

Hal ini menunjukkan bahwa putusan hakim itu tidak hanya mempertimbangkan dimensi yuridis dogmatik semata, tapi juga 
memuat pertimbangan nilai keadilan sosial yang menjadikan pertimbangan majelis hakim bersifat paripurna dan menyeluruh, sebelum menjatuhkan suatu putusan pemidanaan pada perkara tindak pidana korupsi.

\section{a) Subjek Hukum}

Subjek hukum (natuurlijke persoon) tindak pidana tidak terlepas pada sistem pembebanan tanggung jawab pidana yang dianut dalam hukum pidana umum sebagaimana telah diatur dalam KUHP. Dalam artian di sini bahwa pertanggungjawaban tersebut bersifat pribadi atau orang yang dibebani tanggung jawab pidana dan dipidana hanyalah orang atau pribadi si pembuat tindak pidana (Chazawi, 2014: 342).

Pertanggungjawaban pribadi tidak dapat dibebankan pada orang yang tidak berbuat tindak pidana atau subjek hukum lain. Dalam hal ini berlaku prinsip dalam hukum pidana yang dikenal dengan istilah strict liability atau pertanggungjawaban pidana secara langsung, dan tidak dikenal istilah vicarious liability atau pertanggungjawaban yang dapat diwakili oleh subjek hukum yang lain (Sjahdeini, 2007: 45).

Subjek hukum orang tindak pidana korupsi telah ditentukan jelas dan tegas dalam Undang-Undang Pemberantasan Tindak Pidana Korupsi. Bersumber pada undang-undang tersebut, subjek hukum orang tindak pidana korupsi dapat ditentukan melalui dua cara, yaitu: pertama, disebutkan sebagai subjek hukum orang pada umumnya, artinya tidak ditentukan kualitas pribadinya. Kata permulaan pada kalimat rumusan tindak pidana yang menggambarkan atau menyebutkan subjek hukum tindak pidana korupsi dengan sebutan "setiap orang." Kedua, menyebutkan kualitas pribadi dari subjek hukum orang tersebut, semisal kapasitas si pembuat tindak pidana baik berupa sebagai pegawai negeri atau penyelenggara negara (Pasal 8, 9, 10, 11, 12), pemborong ahli bangunan (Pasal 7 ayat (1) huruf a), hakim (Pasal 12 huruf c), advokat (Pasal 12 huruf d), saksi (Pasal 24), dan bahkan tersangka (Pasal 22 jo. Pasal 28).

Subjek hukum orang di sini tidak terlepas dari peran dan kedudukan subjek hukum ("setiap orang") yang didakwa telah melakukan perbuatan tindak pidana korupsi. Peran dan kedudukan seorang terdakwa dalam suatu perkara tindak pidana korupsi menjadi salah satu tolok ukur atau kriteria bagi hakim dalam menjatuhkan pidana di bawah batas minimum khusus. Maksud peran atau kedudukan terdakwa di sini yaitu pada saat ia melakukan tindak pidana, apakah terdakwa hanya seorang diri ataukah ada orang lain yang juga turut melakukannya. Peran atau kedudukan terdakwa di dalam terjadinya tindak pidana korupsi ini dapat menjadi pertimbangan hakim dalam menjatuhkan putusannya, terutama dalam hal penentuan berat ringannya pidana yang dijatuhkan.

Merujuk pada Putusan Nomor 2399 K/PID.SUS/2010, penjatuhan putusan hakim di tingkat pengadilan tinggi yang mengesampingkan ketentuan pidana minimum khusus sekaligus menganulir putusan hakim di tingkat pertama (yang 
menjatuhkan hukuman pidana empat tahun penjara) dengan pertimbangan bahwa pengadilan tingkat tinggi sependapat dengan pertimbangan putusan hakim tingkat pertama, di mana terdakwa terbukti secara sah dan meyakinkan bersalah melakukan tindak pidana korupsi sebagaimana yang didakwakan kepadanya.

Pertimbangan putusan hakim di tingkat pertama tersebut telah diambil alih dan dijadikan pertimbangan bagi hakim pengadilan di tingkat tinggi dalam memutus perkara ini terkecuali mengenai pemidanaan yang dijatuhkan terhadap terdakwa. Di mana putusan pemidanaan di tingkat tinggi tersebut berubah dari pidana penjara empat tahun dengan denda Rp.200 juta dan pidana uang pengganti Rp2.900.000,- menjadi pidana penjara satu tahun dengan denda Rp.200 juta dan pidana uang pengganti Rp2.900.000,-. Adapun yang menjadi pertimbangan hakim di tingkat pengadilan tinggi pada perkara ini menilai bahwa terdakwa bukanlah merupakan "aktor intelektual" pada kasus tersebut.

Penjatuhan pemidanaan pada putusan majelis hakim pengadilan tinggi dan putusan majelis hakim tingkat kasasi yang di bawah batas minimum yang menganulir putusan majelis hakim pengadilan tingkat pertama dengan pemidanaan empat tahun penjara dengan pertimbangan bahwa pengadilan tingkat tinggi dan pengadilan tingkat kasasi sependapat dengan pertimbangan hakim tingkat pertama dalam putusannya. Bahwa terdakwa terbukti dengan sah dan menyakinkan bersalah melakukan tindak pidana sebagaimana yang didakwakan kepadanya, dan pertimbangan hakim tingkat pertama tersebut diambil alih dan dijadikan pertimbangan pengadilan tingkat di atasnya dalam memutus perkara ini. Namun dari sisi sanksi hukum yang dijatuhkan, pengadilan tingkat tinggi dan pengadilan tingkat kasasi berpendapat hal itu terlalu berat. Hal itu didasari bahwa terdapat saksi lain yang merupakan terdakwa dalam berkas perkara lain yang dinilai oleh majelis hakim sebagai aktor intelektual kasus tersebut.

Berdasarkan pertimbangan judex factie dalam menilai peran subjek hukum di atas dapatlah disimpulkan bahwa salah satu kriteria untuk mengukur sejauh mana pejatuhan pemidanaan di bawah batas minimum dapat dilakukan oleh majelis hakim dengan pertimbangan pada faktor peran terdakwa dalam kasus tindak pidana korupsi yang didakwakan. Bahkan terdakwa dalam hal ini tidak berperan signifikan, terdakwa hanya mendapat fee dari penggunaan nama perusahaan yang dipinjam untuk memenuhi syarat formalitas pengajuan tender proyek pengadaan pakaian dinas tersebut.

Subjek hukum orang tindak pidana korupsi menjadi salah satu tolok ukur yang patut untuk dikaji terkait dalam hal memformulasikan kembali ketentuan pemidanaan minimum dalam UndangUndang Pemberantasan Tindak Pidana Korupsi. Subjek hukum orang di sini tidak terlepas dari peran dan kedudukan subjek hukum ("setiap orang") yang didakwa telah melakukan perbuatan tindak pidana korupsi. 
Peran dan kedudukan seorang terdakwa dalam suatu perkara tindak pidana korupsi menjadi salah satu tolok ukur atau kriteria bagi hakim dalam menjatuhkan pidana di bawah batas minimum yang telah ditentukan dalam undang-undang. Peran atau kedudukan terdakwa yang dimaksudkan di sini adalah pada saat melakukan tindak pidana, apakah terdakwa hanya seorang diri ataukah ada orang lain yang juga turut melakukannya. Peran atau kedudukan terdakwa di dalam terjadinya tindak pidana korupsi inilah yang menjadi pertimbangan hakim dalam menjatuhkan putusannya pada perkara a quo, terutama dalam hal penentuan berat ringannya pidana yang dijatuhkan.

\section{b) Kualitas Perbuatan}

Penulis membagi perbuatan tindak pidana korupsi menjadi dua kualifikasi sebagai dasar pertimbangan hakim dalam menjatuhkan putusan pemidanaan di bawah ketentuan pidana minimum khusus berdasarkan Undang-Undang Pemberantasan Tindak Pidana Korupsi, yaitu tindak pidana korupsi yang aktif dan pasif. Pembatasan kualifikasi perbuatan tindak pidana korupsi yang aktif berdasarkan pemikiran penulis adalah perbuatan tindak pidana korupsi yang dilakukan oleh subjek hukum yang bersifat aktif dengan memanfaatkan peran kecil dari subjek hukum lainnya yang bersifat pasif.

Pembatasan kualifikasi perbuatan tindak pidana korupsi yang pasif tersebut adalah perbuatan yang dilakukan oleh subjek hukum yang bersifat pasif dalam melakukan perbuatan tindak pidana korupsi, sehingga yang aktif adalah subjek hukum lain yang membutuhkan pemenuhan suatu kepentingan diri sendiri atau orang lain. Untuk memberikan batasan pembedaan antara pelaku tindak pidana korupsi yang aktif dan pasif, penulis memberikan batasan yang jelas bahwa untuk dapat disebut sebagai pelaku tindak pidana korupsi yang pasif, maka ia tidak harus memenuhi kriteria pelaku tindak pidana korupsi yang aktif dengan tipologi telah terjadi korupsi transaktif (Pryhantoro, 2016: 44), yang menunjukkan adanya kesepakatan timbal balik antara pihak yang memberi dan menerima demi keuntungan bersama, dan kedua pihak sama-sama aktif menjalankan perbuatan tersebut.

Pada Putusan Nomor 2399 K/PID. SUS/2010 dapatlah diamati bahwa kualitas perbuatan tindak pidana korupsi yang dilakukan terdakwa cenderung bersifat pasif. Bahwa dalam pertimbangan putusan majalis hakim tingkat kasasi pada perkara $a$ $q u o$, terdakwa hanya mendapat fee sebesar 5\% dari nilai proyek pakaian, sedangkan pihak lain yang mendapat proyek pekerjaan menjahit pakaian tersebut tidak diproses hukum. Demikian juga saksi-saksi lain yang merupakan terdakwa dalam perkara terpisah seharusnya juga dijadikan sebagai tersangka, karena merekalah yang secara aktif turut merekayasa proyek pengadaan pakaian dinas di lingkungan Sekretariat DPRD Kabupaten Singkawang sejumlah 130 potong pakaian dengan pagu anggaran Rp.64.948.000,-.

Pada proses pembuktian persidangan menunjukkan adanya fakta hukum bahwa 
kualitas perbuatan tindak pidana korupsi yang bersifat aktif berada pada orang lain yang merupakan terdakwa pada berkas perkara yang lain pula (splitsing) yang memegang peranan selaku PPK dalam pengadaan proyek pengadaan pakaian dinas tersebut. Terdakwa pada perkara a aquo hanyalah pihak yang diperalat oleh PPK.

Pertimbangan hukum majelis hakim tingkat kasasi dengan Putusan Nomor 2399 K/PID.SUS/2010 telah terurai jelas bahwa perbuatan terdakwa sekalipun itu telah terbukti melakukan perbuatan memperkaya diri sendiri dan orang lain yang dapat merugikan keuangan negara atau perekonomian negara, namun kualitas perbuatan terdakwa oleh majelis hakim dipandang tidaklah pantas untuk dijatuhi pemidanaan minimum yang telah diatur dalam Undang-Undang Pemberantasan Tindak Pidana Korupsi.

Penulis menilai bahwa pertimbangan majelis hakim dalam menjatuhkan putusan pemidanaan yang menerobos ketentuan pemidanaan minimum atas dasar kualitas perbuatan terdakwa didasarkan pada dua hal, yaitu: pertama, hakim telah mempertimbangkan jenis perbuatan apa yang seharusnya dapat dijatuhi ketentuan pemidanaan minimum; dan kedua, hakim telah menilai sejauh mana peran terdakwa dalam melakukan rangkaian perbuatan tindak pidana korupsi yang didakwakan.

Mengenai dasar pertama di atas, penulis berpandangan majelis hakim telah mempertimbangkan bahwa dalam menjatuhkan putusan pemidanaan tidak dapat serta merta menilai bahwa setiap perbuatan terdakwa yang terbukti memenuhi unsur tindak pidana korupsi kesemuanya dapat dijatuhi ketentuan pemidanaan minimum. Majelis hakim pun dalam hal ini menilai setiap jenis perbuatan yang dilakukan oleh terdakwa, apakah itu termasuk kategori biasa, sedang ataupun berat. Sekalipun kesemua kategori tersebut memenuhi unsur pasal tindak pidana korupsi yang didakwakan. Dengan tetap mempertimbangkan aspek nilai keadilan, seharusnya putusan pemidanaan pun harus sesuai dengan jenis perbuatan pidana yang dilakukan oleh terdakwa.

Majelis hakim telah mempertimbangkan bahwa bila kualitas perbuatan itu memang termasuk kategori berat maka hukuman pemidanaan minimum maupun pemidanaan maksimum sekalipun layak diberikan kepada terdakwa. Namun sebaliknya, yang tidak ingin diharapkan apabila jenis perbuatan pidana yang dilakukan oleh terdakwa termasuk kategori ringan, lalu pidana yang dijatuhkannya pun amatlah berat sesuai dengan ketentuan pemidanaan minimum akan memberikan kesan bahwa putusan tersebut dapat mencederai nilai-nilai keadilan, khususnya bagi seorang terdakwa pelaku tindak pidana korupsi. Berlanjut pada dasar kedua di atas, di mana hal tersebut erat kaitannya dengan ketentuan Pasal 55 KUHP yang lazim digunakan sebagai pasal penunjang dalam mendakwa para pelaku tindak pidana korupsi selain menggunakan pasal-pasal utama dalam Undang-Undang Pemberantasan Tindak Pidana Korupsi. Pasal 55 KUHP mengatur mengenai 'membantu melakukan' tindak pidana 
yang tentunya mengatur tentang peran atau kapasitas pelaku tindak pidana dalam melakukan kejahatan. Pada pertimbangan hukum putusan pengadilan pada perkara $a$ $q u o$, majelis hakim menilai bahwa terdakwa tidak memiliki peran yang sangat signifikan atas perbuatan tindak pidana korupsi yang telah terbukti dilakukan. Hal ini dikarenakan terdapat peran yang lebih signifikan atau lebih aktif yang dilakukan oleh subjek hukum lain atas peristiwa tindak pidana korupsi pada perkara yang dimaksud.

Berdasarkan uraian penulis di atas, kiranya dapat ditemukan adanya perbedaan mendasar mengenai peran dari setiap pelaku tindak pidana, terutama dari setiap peran dalam melakukan tindak pidana terdapat perbedaan mendasar dari 'turut melakukan' tindak pidana dengan 'membantu melakukan' tindak pidana. Sebagaimana Pasal 55 KUHP yang mengatur delik penyertaan yang mengatur bahwa unsur 'turut melakukan' tindak pidana terdapat kerja sama yang disadari antara para pelaku dan mereka bersama-sama melaksanakan kehendak tersebut, di mana para pelaku memiliki tujuan tertentu atas dasar niat dalam melakukan tindak pidana tersebut.

Ajaran hukum pidana 'turut melakukan' dapat dibedakan lagi menjadi empat bagian, yaitu: pelaku pelaksana (plegen); pelaku sebagai penyuruh (doenplegen); pelaku peserta (medeplegen); dan pembujuk/penganjur (uitlokken). Sedangkan dalam 'membantu melakukan,' kehendak dari orang yang membantu melakukan hanyalah untuk membantu pelaku utama mencapai tujuannya, tanpa memiliki tujuan sendiri. c). Nilai Kerugian Keuangan Negara

Kriteria kerugian keuangan negara yang merupakan salah satu akibat dari perbuatan tindak pidana korupsi, menjadi salah satu tolok ukur atau kriteria bagi hakim dalam menjatuhkan putusan di bawah ketentuan pemidanaan minimum. Pada Putusan Nomor 2399 K/PID.SUS/2010 terhadap terdakwa kemudian majelis hakim kasasi memvonis satu tahun penjara. Vonis ini lebih rendah dari tuntutan jaksa penuntut umum yang mengacu pada ancaman pemidanaan minimum dalam Pasal 2 ayat (1) Undang-Undang Pemberantasan Tindak Pidana Korupsi, yaitu pidana penjara minimum selama empat tahun dan denda paling sedikit Rp.200 juta.

Salah satu pertimbangan majelis hakim kasasi adalah kriteria unsur kerugian keuangan negara akibat yang timbul dari perbuatan terdakwa, terkait dengan kerugian keuangan negara atau perekonomian negara tidak terlampau besar, hanya Rp.2.900.000,-. Nilai ini tentu sangat kecil apabila dibandingkan dengan nilai korupsi yang dilakukan oleh terdakwa mantan Bupati Lampung Timur sebesar 10 milyar lebih. Atau nilai korupsi yang dilakukan oleh terdakwa mantan Bendahara Umum Partai Demokrat yang divonis empat tahun. Hal semacam ini tentu sangat tidak adil jika vonis yang sama dijatuhkan terhadap terdakwa pada Putusan Nomor 2399 K/PID.SUS/2010 di mana nilai yang diperoleh dari hasil tindak pidana korupsi relatif sangat kecil.

Sejatinya keberadaan unsur kerugian negara merupakan pintu masuk dan 
salah satu kunci utama sukses tidaknya upaya perampasan dan pengembalian aset perolehan hasil korupsi di Indonesia. Adanya kerugian negara atau perekonomian negara menjadi unsur dari tindak pidana korupsi, sebagaimana diatur hanya ada dalam Pasal 2 dan Pasal 3 Undang-Undang Pemberantasan Tindak Pidana Korupsi, kcuali dengan suap dan gratifikasi, tindakan korupsi telah menimbulkan kerugian negara yang sangat signifikan. Oleh ketentuan pemidanaan minimum yang secara legalistik dianut dalam UndangUndang Pemberantasan Tindak Pidana Korupsi. Untuk lebih memudahkan gambaran uraian dari pertimbangan judex factie hakim pada perkara a aquo di atas, penulis mencoba menampilkan alur legal reasoning sehingga hakim dengan yakin dapat menerobos ketentuan pemidanaan minimum seperti yang dapat diamati pada gambar di bawah ini:

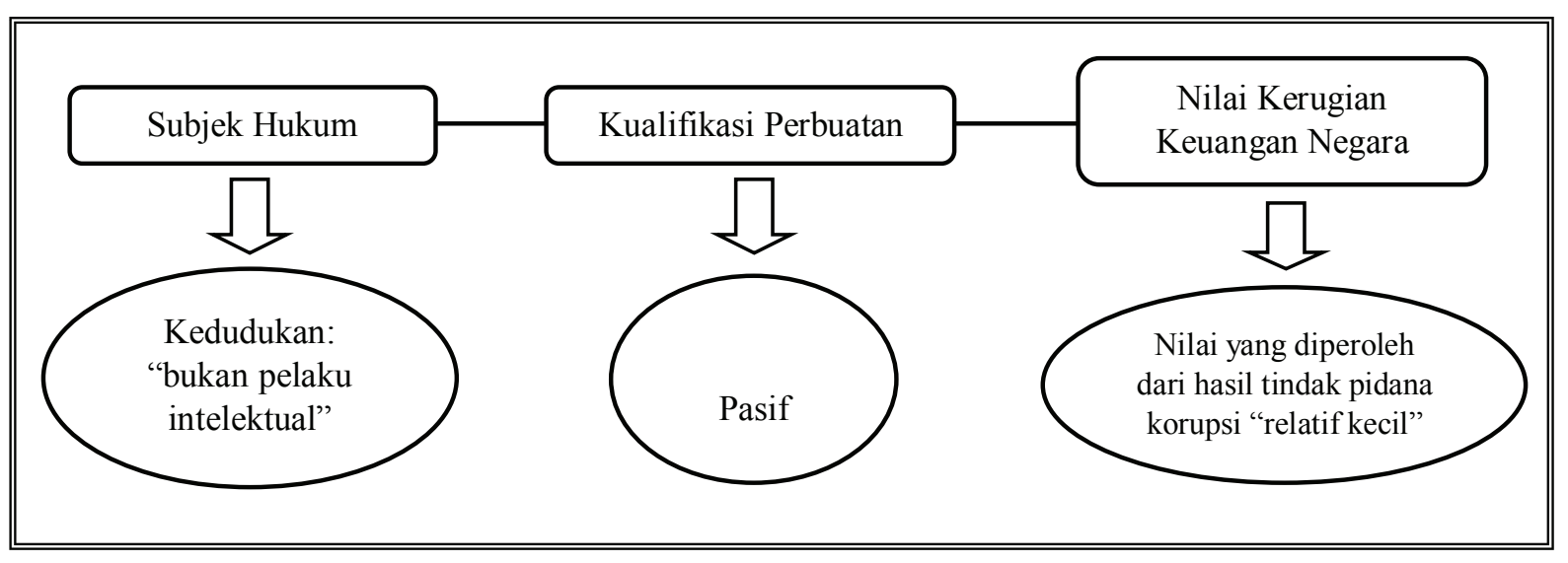

Gambar 1. Alur Pertimbangan Judex Factie Hakim pada Perkara a quo Sumber: Data Primer, diolah penulis (2017)

karenanya, tentunya sangatlah tidak adil, bilamana seseorang terdakwa yang terbukti merugikan keuangan negara dengan nilai relatif sangat kecil dipidana penjara selama empat tahun dan pidana denda sebesar Rp.200 juta sesuai ketentuan dalam Pasal 2 ayat (1) Undang-Undang Pemberantasan Tindak Pidana Korupsi, sebagaimana pasal yang diterapkan kepada terdakwa dalam perkara a aquo.

Berdasarkan pertimbangan hukum majelis hakim tersebut pada Putusan Nomor 2399 K/PID.SUS/2010, maka penjatuhan pemidanaan kepada terdakwa dinilai tidak adil bila tetap menerapkan
Tiga hal yang menjadi pertimbangan judex factie dari hakim terhadap Putusan Nomor 2399 K/PID.SUS/2010 tersebut di atas yang meliputi: subjek hukum; kualifikasi perbuatan; dan nilai kerugian keuangan negara, menurut analisis penulis adalah sudah tepat dan benar untuk dapat menjadi pertimbangan hukum (legal reasoning) bagi hakim dalam memeriksa, menilai, dan memutus perkara tindak pidana korupsi yang mengesampingkan penerapan ketentuan pemidanaan minimum.

Hal ini diharapkan ke depan agar dapat diakomodasi dalam revisi UndangUndang Pemberantasan Tindak Pidana 
Korupsi sebagai ruang dari aspek legalitas bagi hakim agar tidak terjadi lagi distorsi yang menimbulkan pemasalahan, friksi, ataupun perdebatan terhadap putusan pemidanaan yang menerobos ketentuan pemidanaan minimum pada setiap perkara tindak pidana korupsi.

Bagi penulis dengan adanya putusan Mahkamah Agung pada perkara a quo yang mengesampingkan ketentuan pemidanaan minimum tersebut merupakan pilihan tepat dan benar yang telah diambil oleh hakim sekalipun terdapat adanya unsur infra petita pada putusan tersebut, di mana putusan hakim tersebut lebih mendahulukan aspek keadilan yang bersifat substantif dibandingkan dengan aspek kepastian hukum yang cenderung bersifat prosedural.

\section{KESIMPULAN}

Dari uraian hasil dan pembahasan dalam kajian di atas, maka penulis dapat merumuskan kesimpulan bahwa putusan pengadilan tindak pidana korupsi yang menerobos ketentuan pemidanaan minimum dalam Undang-Undang Pemberantasan Tindak Pidana Korupsi pada dasarnya diperbolehkan, sepanjang putusan hakim yang infra petita tersebut memiliki esensi ratio legis yang kuat dan dapat dipertanggungjawabkan atas dasar alasan pertimbangan nilai keadilan dan pertimbangan judex factie, sebagaimana pada perkara $a$ quo.

Pada pertimbangan nilai keadilan, hakim telah menunjukkan bahwa penegakan hukum tidak hanya menegakkan hukum secara substansial normatif semata sebagaimana yang telah diperintahkan undang-undang, tapi tetap melihat kadar kesalahan seseorang yang melakukan tindak pidana korupsi atas dasar prinsip dan nilai-nilai keadilan. Sedangkan pada pertimbangan judex factie, hakim memiliki tiga unsur pertimbangan, yaitu: a) subjek hukum: terdakwa bukan merupakan pelaku intelektual dari munculnya kasus korupsi tersebut; b) kualifikasi perbuatan korupsi terdakwa tergolong pasif; dan c) nilai kerugian keuangan negara yang diperoleh dari hasil korupsi relatif kecil, sehingga hakim kepada terdakwa menjatuhkan putusan di bawah dari batas ketentuan pemidanaan minimum.

\section{SARAN}

Atas dasar ditemukannya beberapa perkara di pengadilan tindak pidana korupsi, di mana hakim tidak memiliki keseragaman berpikir dalam mengadili dan memutus perkara tindak pidana korupsi yang didakwa/dituntut menggunakan ketentuan pemidanaan minimum, maka saran dari penulis adalah diperlukan adanya reformulasi konsep ideal mengenai batasan diberlakukannya ketentuan pemidanaan minimum dalam UndangUndang Pemberantasan Tindak Pidana Korupsi.

Adapun tawaran konsep ideal tersebut oleh penulis dibatasi pada tiga kriteria penilaian oleh hakim yaitu: subjek hukum pelaku tindak pidana korupsi, kualifikasi perbuatan pelaku tindak pidana korupsi, dan nilai kerugian keuangan negara. Adanya tiga kriteria ini semata-mata untuk memberikan batasan positivistik dan legalisasi dari penjatuhan pidana di bawah minimum yang ditetapkan dalam Undang-Undang Pemberantasan Tindak Pidana Korupsi, sehingga penjatuhan pidana minimum pada perkara tindak pidana korupsi tidak lagi menjadi polemik atau permasalahan dalam proses penegakan hukum dan pemberantasan tindak pidana korupsi di Indonesia. 


\section{DAFTAR ACUAN}

Ali, A., \& Heryani, W. (2012). Sosiologi hukum kajian empiris terhadap pengadilan. Jakarta: Kencana Prenada Media Group.

Anggraeni, R. (2011, Desember). Pengusungan pola pikir positivisme hukum dalam perkara korupsi (Kajian Putusan Nomor 207/PID.B/2008/ PN.MPW). Jurnal Yudisial, 4(3), 262-278.

Arief, B.N. (2002). Bunga rampai kebijakan hukum pidana. Bandung: Citra Aditya Bakti.

Arto. (2001). Mencari keadilan. Yogyakarta: Pustaka Pelajar.

Askin, M. (2012, November). Penerapan sanksi pidana dalam kasus tipikor. Varia Peradilan, XXVII(324), 38-50.

Bertens, K. (2013). Sejarahfilsafat Yunani. Yogyakarta: Kanisius.

Budiman, M. (2016, Desember). Problematika penerapan Pasal 2 dan 18 Undang-Undang Pemberantasan Tindak Pidana Korupsi (Kajian Putusan Nomor 1283 K/PID.SUS/2013). Jurnal Yudisial, 9(3), 303-315.

Chazawi, A. (2014). Hukum pidana materiil \& formil korupsi di Indonesia. Malang: Bayu Media Publishing.

Friedrich, C.J. (2004). Filsafat hukum perspektif historis. Bandung: Nuansa \& Nusamedia.

Huda, C. (2011). Dari tiada pidana tanpa kesalahan menuju kepada tiada pertanggungjawaban pidana tanpa kesalahan, tinjauan kritis terhadap teori pemisahan tindak pidana \& pertanggungjawaban pidana. Jakarta: Kencana.

Marzuki, P.M. (2010). Penelitian hukum. Jakarta: Kencana Prenada Media Group.

Melani. (2014, Agustus). Disparitas putusan terkait penafsiran Pasal 2 dan 3 UU Pemberantasan Tindak Pidana Korupsi (Kajian Terhadap 13 Putusan Pengadilan Tipikor Bandung Tahun 2011-2012). Jurnal Yudisial, 7(2), 103-116.

Mertokusumo, S. (2010). Penemuan hukum. Yogyakarta: Universitas Atma Jaya Press.

Mulyadi, L. (2007). Tindak pidana korupsi di Indonesia, normatif, teori, praktik \& masalahnya. Bandung: Alumni.

Pryhantoro, E.H. (2016). Korupsi dalam perspektif teori sosial kontemporer. Surabaya: Agra Vidya.

Rumadan, I. (2013, Desember). Penafsiran hakim terhadap ketentuan pidana minimum khusus dalam Undang-Undang Tindak Pidana Korupsi. Jurnal Hukum dan Peradilan, 2(3), 379-404.

Sjahdeini, S.R. (2007). Pertanggungjawaban pidana korporasi. Jakarta: Grafiti Pers.

Soekanto, S., \& Mamudji, S. (2011). Penelitian hukum normatif. Jakarta: Rajawali Pers.

Suwito et al. (2017, Agustus). Deviation on special minimum criminal provision in the verdict of corruption court. International Journal of Humanities and Social Science Invention, 6(8), 14-21.

Suwito. (2015, April). Putusan hakim yang progresif dalam perkara perdata, telaah "Kasus Pohon Mangga”. Hasanuddin Law Review, 1(1), 101113

. (2017, September). Putusan pengadilan tindak pidana korupsi yang menerobos ketentuan pidana minimum khusus sebagai bentuk penemuan hukum oleh hakim. Khairun Law Journal, 1(1), 48-61.

Van Apeldoorn, L.J. (2011). Pengantar ilmu hukum. Jakarta: Pradnya Paramita. 